\title{
Cicletanine Hydrochloride
}

National Cancer Institute

\section{Source}

National Cancer Institute. Cicletanine Hydrochloride. NCI Thesaurus. Code C101534.

The hydrochloride salt of a dihydropyridine derivative with diuretic and antihypertensive activity. Cicletanine exerts thiazide-like diuretic activity. In addition, this agent inhibits protein kinase $\mathrm{C}(\mathrm{PKC})$ and is able to reverse vasoconstriction through the inhibition of PKC-mediated inhibition of Na/K-AT Pase phosphorylation. 